\title{
Effect of bacterial inoculation on co-composting of lavender (Lavandula angustifolia Mill.) waste and cattle manure
}

\author{
Babett Greff ${ }^{1}$ (D) Jenő Szigeti ${ }^{1} \cdot$ Ágnes Varga ${ }^{1} \cdot$ Erika Lakatos $^{1} \cdot$ András Sáhó $^{2} \cdot$ László Varga $^{1}$ (D)
}

Received: 5 February 2021 / Accepted: 25 May 2021 / Published online: 31 May 2021

(c) The Author(s) 2021

\begin{abstract}
The primary purpose of this study was to investigate the influence of Cellulomonas flavigena and Streptomyces viridosporus, as a bacterial inoculant, on the compostability of post-extraction lavender waste. The major physicochemical, microbiological, and biological properties of the composting materials were monitored for 161 days. The technology developed was shown to improve the compostability of recalcitrant herbal residues. The use of lavender waste beneficially affected the composting process by extending the thermophilic phase, accelerating the degradation of organic matter, and elevating the viable counts of useful microorganisms; however, adverse effects were also observed, including an increased carbon-to-nitrogen ratio (19.05) and a decreased germination index (93.4\%). Bacterial inoculation was found to preserve the nitrogen content (2.50\%) and improve the efficiency of biodegradation. The Salmonella- and Escherichia coli-free final composting products were mature, stable, and ready for soil application. To the authors' knowledge, no previous research has investigated the compostability of lavender waste. Likewise, this is the first study that has used strains of $C$. flavigena and $S$. viridosporus in combination to facilitate a composting process.
\end{abstract}

Keywords Compost $\cdot$ Lavender $\cdot$ Herb $\cdot$ Cellulomonas $\cdot$ Streptomyces

\section{Introduction}

Herbs are extensively used for their medicinal, antipathogenic, aromatic, and culinary properties by the pharmaceutical, cosmetic, and food industries (Greff et al. 2021; Sánchez-Vioque et al. 2013; Semeniuc et al. 2017). Their beneficial effects have primarily been attributed to their essential oil (EO) content. These volatile oils are complex mixtures of diverse components including terpenes, phenolic

Babett Greff

greff.babett@sze.hu

Ágnes Varga

varga.agnes@sze.hu

András Sáhó

asaho@kisalfoldi.hu

László Varga

varga.laszlo@sze.hu

1 Department of Food Science, Faculty of Agricultural and Food Sciences, Széchenyi István University, 15-17 Lucsony Street, Mosonmagyaróvár 9200, Hungary

2 Kisalföldi Agricultural Ltd, Fő út 1., Nagyszentjános 9072, Hungary compounds, ketones, ethers, esters, aldehydes, and alcohols obtained from various herbal parts such as seeds, roots, rhizomes, leaves, fruits, flowers, buds, and barks (SánchezVioque et al. 2013; Shaaban et al. 2012).

Lavender (Lavandula angustifolia Mill.), an evergreen bushy shrub, is one of the major species of the family Lamiaceae. It is commercially cultivated in many countries, e.g., France, Hungary, Bulgaria, China, the UK, the USA, Australia, Portugal, and Spain (Rashed et al. 2019; Yazdani et al. 2013). Lavender EO is among the best-selling over-thecounter herbal remedies for stress and anxiety with a global yearly production of approximately 200 tonnes (LesageMeessen et al. 2018; López et al. 2017). The rapidly growing EO production, the low EO content of herbs, and the inefficiency of extraction processes result in huge amounts of herbal residues rich in biologically active compounds worldwide (Greff et al. 2021; Ratiarisoa et al. 2016; Saha and Basak 2020; Slavov et al. 2020). In France alone, over 20,000 tonnes of solid residues of lavandin- and lavenderdistilled straws are generated annually (Lesage-Meessen et al. 2018).

The traditional treatments (i.e., incineration or disposal in landfills) of herbal residues are environmentally 
unfriendly and expensive (de Elguea-Culebras et al. 2016; Deka et al. 2011; Ibrahim et al. 2017; Tian et al. 2017; Yohalem and Passey 2011). In addition, they are a waste of precious resources (Tian et al. 2017). In recent years, recycling and resource recovery have emerged as the most promising options for sustainable management of herbal wastes (Singh and Suthar 2012). Composting is an effective way to stabilize and reuse post-extraction wastes through microbial decomposition of biodegradable materials under controlled conditions (Zhang et al. 2011). However, the post-extraction residues of lavender can be difficult to biotransform because they are rich in cellulose, hemicellulose, lignins, and other components including lactones, terpenes, and phenolic compounds (LesageMeessen et al. 2015). Various biological methods, such as the addition of co-substrates (co-composting) or microbial inoculation during composting, may be used to overcome these difficulties. Co-composting with herbal wastes tends to increase the rate of organic matter $(\mathrm{OM})$ degradation by microorganisms and it often results in improved compost quality with high antipathogenic properties (Zhou et al. 2016, 2018). However, the use of herbal residues may at times negatively influence the composting process because an increased lignocellulose content and the remaining secondary metabolites can inhibit nutrient cycling, litter decomposition, and seed germination (Bohacz 2019a; De Martino et al. 2010; Guénon et al. 2017; Shang et al. 2016; Zhang et al. 2019). Inoculation of the waste material with specific microbial cultures may stimulate the biological degradation of OM, thus improving final compost quality (Huang et al. 2015).

Since only limited information is available in the literature on the compostability of herbal residues, the objective of this study was to produce a mature compost by utilizing the distillation waste of lavender, cattle manure, and straw. A mixed culture of Cellulomonas flavigena and Streptomyces viridosporus strains was applied to improve the co-composting process and the quality of the end product. Temperature, $\mathrm{pH}$ value, moisture content, and microbial density (i.e., viable counts of mesophilic and thermophilic microorganisms, cellulose-degrading bacteria, streptomycetes, and fungi) were monitored in the compost bins over a period of 161 days. In addition, OM, total organic carbon (TOC), total nitrogen (TN), and acid-insoluble lignin contents, carbon-tonitrogen $(\mathrm{C} / \mathrm{N})$ ratio, biodegradability coefficient, germination index (GI), and the presence or absence of potentially pathogenic enterobacteria (Escherichia coli and Salmonella spp.) were also determined in the final products to evaluate compost maturity. To our knowledge, no previous research has investigated the compostability of post-extraction lavender waste. Likewise, as far as we know, this is the first study that has used strains of $C$. flavigena and $S$. viridosporus in combination to facilitate a composting process.

\section{Materials and methods}

\section{Preparation of composts and sampling}

Outdoor pilot-scale composting trials were carried out at Kisalföldi Agricultural Ltd (Nagyszentjános, Hungary) from September 2019 through February 2020, for a total of 161 days. Compost bins $\left(1 \mathrm{~m}^{3}\right)$ were made from pallets and were covered with mesh and insulated with styrofoam. Each bin contained $250 \mathrm{~kg}$ of waste material as follows:

- Control compost (CC): 90\% cattle manure and 10\% barley straw.

- Control lavender waste compost (CLC): $60 \%$ lavender waste, $30 \%$ cattle manure, and $10 \%$ barley straw.

- Lavender waste compost with bacterial inoculation (LCI): $60 \%$ lavender waste, $30 \%$ cattle manure, and $10 \%$ barley straw inoculated with the mixed culture of $C$. flavigena NCAIM B.01383 and S. viridosporus NCAIM B.02369 (for more details, see subsection entitled Preparation of lavender waste compost with bacterial inoculation).

The composition of raw materials used to make the composts is shown in Table 1. Post-extraction lavender waste, cattle manure, and barley straw batches were provided by the same supplier (Kisalföldi Agricultural Ltd, Nagyszentjános, Hungary). It should also be noted that lavender was harvested from the same location and the lavender biomass was produced by water distillation.

Each mixture was carefully homogenized, and the initial moisture content was adjusted to $55 \%$ by water addition. Over the months, the content of the compost bins was turned over manually three times to aerate the mixture. Lost water was replaced by adding tap water to the bins.

On days $0,8,15,21,42,56,78$, and 161 , subsamples were taken from five representative points in the bins. These subsamples were mixed thoroughly (Ryckeboer et al., 2003) to obtain homogeneous samples of approximately $500 \mathrm{~g}$ each, which were then divided into two parts.

Table 1 Major parameters (on dry weight basis) of raw materials used for the composting trials

\begin{tabular}{lccc}
\hline Parameter & $\begin{array}{l}\text { Post-extraction } \\
\text { lavender waste }\end{array}$ & Cattle manure & Barley straw \\
\hline Moisture (\%) & $52.84 \pm 5.27$ & $73.43 \pm 1.14$ & $25.62 \pm 7.54$ \\
Total solids (\%) & $47.16 \pm 5.27$ & $26.57 \pm 1.14$ & $74.38 \pm 7.54$ \\
Organic matter (\%) & $91.91 \pm 0.69$ & $84.12 \pm 0.43$ & $93.52 \pm 0.11$ \\
Total organic carbon & $51.06 \pm 0.38$ & $46.73 \pm 0.24$ & $51.96 \pm 0.06$ \\
$(\%)$ & & & \\
Total nitrogen (\%) & $1.37 \pm 0.04$ & $1.68 \pm 0.08$ & $0.55 \pm 0.01$ \\
\hline
\end{tabular}

All values are means \pm SD based on three observations 
One part was used for chemical analysis after natural air drying, whereas the other part of the fresh sample was used immediately for determination of microbiological properties, $\mathrm{pH}$ value, and GI.

\section{Preparation of lavender waste compost with bacterial inoculation}

The mixed waste consisted of solid residues of extracted lavender $(60 \%)$ and cattle manure (30\%). In addition, barley straw $(10 \%)$ was used as a bulking agent to give sufficient air-filled porosity and structure to the composting piles and maintain the required aerobic conditions (Adhikari et al. 2009). Cellulolytic and lignin-degrading strains of C. flavigena (NCAIM B.01383) and S. viridosporus (NCAIM B.02369), respectively, were obtained from the National Collection of Agricultural and Industrial Microorganisms (NCAIM; Budapest, Hungary) and were used as a bacterial inoculant. Before inoculation, the bacterial pure cultures were cultivated separately, at $30{ }^{\circ} \mathrm{C}$ for $100 \mathrm{~h}$, in Dubos Salts Broth supplemented with carboxymethyl cellulose (CMC) as the sole carbon source. This liquid culture medium contained (per liter) $0.5 \mathrm{~g}$ of $\mathrm{NaNO}_{3}, 0.5 \mathrm{~g}$ of $\mathrm{K}_{2} \mathrm{HPO}_{4}, 0.5 \mathrm{~g}$ of $\mathrm{MgSO}_{4} \times 7 \mathrm{H}_{2} \mathrm{O}, 1.0 \mathrm{~g}$ of $\mathrm{KCl}, 0.01 \mathrm{~g}$ of $\mathrm{FeSO}_{4} \times 7 \mathrm{H}_{2} \mathrm{O}, 2.0 \mathrm{~g}$ of yeast extract, and $10.0 \mathrm{~g}$ of CMC. The incubated suspensions of $C$. flavigena NCAIM B.01383 $\left(7.1 \times 10^{8} \mathrm{CFU} / \mathrm{mL}\right)$ and $S$. viridosporus NCAIM B.02369 $\left(6.0 \times 10^{7} \mathrm{CFU} / \mathrm{mL}\right)$ were mixed at a ratio of $1: 1$. On day 8 of the composting process, 1 part of inoculant was diluted with 20 parts of water, which was then sprinkled on the composting material at a concentration of $8 \%$ (v/w) while the contents of the bins were turned. The even distribution of the bacterial amendment was thus ensured.

\section{Physicochemical analysis}

Temperature was measured daily with a stainless-steel compost thermometer (Electronic Temperature Instruments, Worthing, UK) inserted in the center of the compost bins. $\mathrm{pH}$ value was determined in a 1:10 (w/v) water-soluble extract using a Jenway $3510 \mathrm{pH}$-meter and combined glass electrode (Keison Products, Chelmsford, UK) standardized with $\mathrm{pH} 7.00$ and 4.00 standard buffer solutions (Merck, Darmstadt, Germany). Moisture content (\%) was assessed by oven-drying the samples at $105^{\circ} \mathrm{C}$ to constant weight, and OM content (\%) was determined by gravimetric loss on ignition (Yeoh et al. 2011). From OM results, TOC percentages and biodegradability coefficients $\left(K_{\mathrm{b}}\right)$ were calculated as follows (Kebibeche et al. 2019; Rashad et al. 2010):
$\operatorname{TOC}(\%)=\frac{\mathrm{OM}(\%)}{1.8}$,

$K_{\mathrm{b}}=\frac{\left(\mathrm{OM}_{\mathrm{b}}-\mathrm{OM}_{\mathrm{e}}\right) \times 100}{\mathrm{OM}_{\mathrm{b}} \times\left(100-\mathrm{OM}_{\mathrm{e}}\right)}$,

where $\mathrm{OM}_{\mathrm{b}}$ and $\mathrm{OM}_{\mathrm{e}}$ are organic matter contents at the beginning and end, respectively, of the composting process. TN content (\%) was determined by the combustion method with a Rapid N Cube analyzer (Elementar Analysensysteme, Langenselbold, Germany) (Su et al. 2016). C/N ratio was calculated based on TOC and TN values. Acid-insoluble lignin, a.k.a. Klason lignin, content was determined according to TAPPI standard method T 222 (TAPPI T 222 om-02 2002) and the final residues were corrected for ash.

\section{Microbiological analysis}

For enumeration of microorganisms, each compost sample was diluted by mixing $10 \mathrm{~g}$ (wet weight) with $90 \mathrm{~mL}$ of sterile saline solution $(0.85 \% \mathrm{NaCl})$ and homogenized thoroughly in a Stomacher 400 Circulator (Seward, Worthing, UK). Further decimal dilutions were made up to $10^{-9}$. The pour plate method was used to enumerate microbes, except for Salmonella spp. where the qualitative presence-absence test was performed, under aerobic conditions. Colony-forming units (CFU), expressed as $\log _{10}$ per gram, were used to report changes in viable counts of various microbial groups in different types of composts.

Plate Count Agar (Biolab, Budapest, Hungary) was used to enumerate mesophilic and thermophilic microorganisms. The inoculated plates were incubated at $30^{\circ} \mathrm{C}$ (mesophiles) or $55^{\circ} \mathrm{C}$ (thermophiles) for $72 \mathrm{~h}$.

Mesophilic and thermophilic cellulose-degrading bacteria were enumerated in Dubos Salts Agar supplemented with CMC (Rajoka and Malik 1997). The inoculated agar plates were incubated for $72-120 \mathrm{~h}$ at $30^{\circ} \mathrm{C}$ and $55^{\circ} \mathrm{C}$, respectively. Cellulase activity was detected by flooding the CMC-containing plates with $0.1 \%$ (w/v) Congo Red solution (Merck) for $30 \mathrm{~min}$ and then rinsed with $1 \mathrm{~N} \mathrm{NaCl}$.

The viable counts of mesophilic and thermophilic streptomycetes were determined in Gauze's Synthetic Medium No. 1 following $72-120 \mathrm{~h}$ of incubation at $30^{\circ} \mathrm{C}$ and $55^{\circ} \mathrm{C}$, respectively. The solid culture medium contained (per liter) $20.0 \mathrm{~g}$ of soluble starch, $1.0 \mathrm{~g}$ of $\mathrm{KNO}_{3}, 0.5 \mathrm{~g}$ of NaCl, $0.5 \mathrm{~g}$ of $\mathrm{MgSO}_{4} \times 7 \mathrm{H}_{2} \mathrm{O}, 0.5 \mathrm{~g}$ of $\mathrm{K}_{2} \mathrm{HPO}_{4}, 0.01 \mathrm{~g}$ of $\mathrm{FeSO}_{4} \times 7$ $\mathrm{H}_{2} \mathrm{O}$, and $15.0 \mathrm{~g}$ of agar. Since this medium is not strictly selective for streptomycetes, only colonies with aerial mycelia were counted (Ryckeboer et al. 2003).

Rose Bengal Chloramphenicol Agar (Biolab) was used for enumeration of mesophilic and thermophilic fungi. 
Incubation was carried out at $25^{\circ} \mathrm{C}$ and $55^{\circ} \mathrm{C}$, respectively, for $72-120 \mathrm{~h}$.

Escherichia coli was enumerated in ChromoBio Coliform Agar (Biolab) following 24-48 h of incubation at $37^{\circ} \mathrm{C}$.

For detection of Salmonella spp., compost samples each weighing $25 \mathrm{~g}$ were homogenized with $225 \mathrm{~mL}$ of Buffered Peptone Water (Biolab) and incubated at $37{ }^{\circ} \mathrm{C}$ for $18 \mathrm{~h}$. From this pre-enrichment medium, $0.1 \mathrm{~mL}$ was transferred to $10 \mathrm{~mL}$ of Rappaport-Vassiliadis Broth (Biolab) and further incubated at $41.5{ }^{\circ} \mathrm{C}$ for $24 \mathrm{~h}$. A loopful of selectively enriched sample was streaked onto Xylose Lysine Deoxycholate Agar (Biolab) and incubated at $37^{\circ} \mathrm{C}$ for $24 \mathrm{~h}$. Red and pink colonies with or without a black center were considered presumptive Salmonella spp., which were then subcultured and their identity was confirmed by appropriate serological and biochemical tests (ISO 6579-1 2017).

\section{Phytotoxicity test}

A seed germination assay was conducted under laboratory conditions to confirm the maturity of composts. Aqueous extracts of compost samples were prepared by shaking $10 \mathrm{~g}$ of sample in $100 \mathrm{~mL}$ of distilled water for $1 \mathrm{~h}$ at $25^{\circ} \mathrm{C}$ and $200 \mathrm{rpm}$, using a water bath shaker (Gyrotory Model G76D; New Brunswick Scientific, Edison, NJ, USA), and the mixtures were then filtered. Seeds of Brassica rapa subsp. chinensis were used for the experiments carried out in triplicate. Ten seeds each were placed on sterile filter paper discs (Merck) in $90 \mathrm{~mm}$ diameter plastic Petri dishes (Greiner Bio-One, Mosonmagyaróvár, Hungary). Filter papers were previously moistened with $5 \mathrm{~mL}$ aliquots of each compost extract. Distilled water served as a control. After incubation at $25^{\circ} \mathrm{C}$ for $72 \mathrm{~h}$ in the dark, the number of germinated seeds was determined. GI was calculated as described by Zucconi et al. (1981).

\section{Statistical analysis}

Most of the results presented in this paper are the means \pm SD of three replicate analyses. The data were subjected to one-way analysis of variance (ANOVA). Significance of difference was set at $p<0.05$ in all cases.

\section{Results and discussion}

\section{Changes in physicochemical properties during composting}

Changes in temperature of the three types of composts are shown in Fig. 1a. Once the composting process started, core temperatures rose steeply, reaching the thermophilic phase $\left(>50{ }^{\circ} \mathrm{C}\right)$ within a day in all compost bins. Temperature remained over $60{ }^{\circ} \mathrm{C}$ for 3,6 , and 7 days in $\mathrm{CC}$, LCI, and CLC piles, respectively, and then a fast decline was observed. However, when the composting material was turned over, thermal reactivation occurred. All things considered, the thermophilic phase lasted for 15, 25, and 16 days in CC, CLC, and LCI, respectively. The temperature of the control pile containing no lavender waste (CC) reached its peak of $76{ }^{\circ} \mathrm{C}$ on day 3 , whereas the corresponding values for CLC and LCI were $73{ }^{\circ} \mathrm{C}$ and $71{ }^{\circ} \mathrm{C}$, respectively, at the same stage. The final cooling phase started on day 50 and, as a result, the core temperature of all three types of composts gradually decreased to $0-2{ }^{\circ} \mathrm{C}$. Although the bins were insulated, the temperature of composts started to decline rapidly due to low ambient winter temperatures.

It should be noted that changes in compost temperature generally reflect the activity of microorganisms and the overall progress of composting ( $\mathrm{Li}$ et al. 2018). The thermophilic phase is a crucial part of the composting process because cellulose and various phytotoxic compounds are degraded by thermophilic bacteria (Zhong et al. 2018). Furthermore, temperatures must exceed $55^{\circ} \mathrm{C}$ for at least three consecutive days to ensure proper disinfection (Zeng et al. 2010; Zhong et al. 2018). The results showed that CC failed to comply with this requirement. In contrast, the use of lavender waste for composting was shown to extend the thermophilic phase, which was, however, 9 days shorter in LCI than in CLC, indicating that inoculation with C. flavigena and $S$. viridosporus could not promote the composting process in this regard.

Microbial activity largely depends on $\mathrm{pH}$ conditions in the composting environment. Most microorganisms, especially bacteria, grow best around neutral $\mathrm{pH}$ values (Pandey et al. 2009). The $\mathrm{pH}$ of the three types of composts ranged between 6.65 and 8.20 over the entire composting period (Fig. 1b). The presence of lavender waste in the compost increased the initial $\mathrm{pH}$ value of CLC and LCI, but the $\mathrm{pH}$ of $\mathrm{CC}$ also rose rapidly from 6.65 to 7.70 by the end of the first week. This must have been due to the production of ammonia from decomposition of proteins and amino acids. With the progress of composting, $\mathrm{pH}$ gradually decreased in all three treatments because of $\mathrm{CO}_{2}$ emissions from degradation of OM (Jiang et al. 2015), nitrification, and formation of low molecular weight fatty acids (Gou et al. 2017). As from day 21, pH followed the same trend for CC and CLC. After turning over on day 42 , a considerable increase in $\mathrm{pH}$ of all three types of composts was observed, which could be explained by additional protein mineralization and decomposition of organic acids (Voběrková et al. 2017). Between days 56 and 78 , the bacterial additive in LCI increased the decomposition rate of organic compounds and the production organic acids. At completion of composting, the final $\mathrm{pH}$ values were in the range of 7.6-8.0, thus complying with the recommended level of $<9$ (Gou et al. 2017). 
Fig. 1 Changes in core temperature (a) and $\mathrm{pH}$ value (b) during the composting process $(C C$ control compost, $C L C$ control lavender waste compost, $L C I$ lavender waste compost with bacterial inoculation)

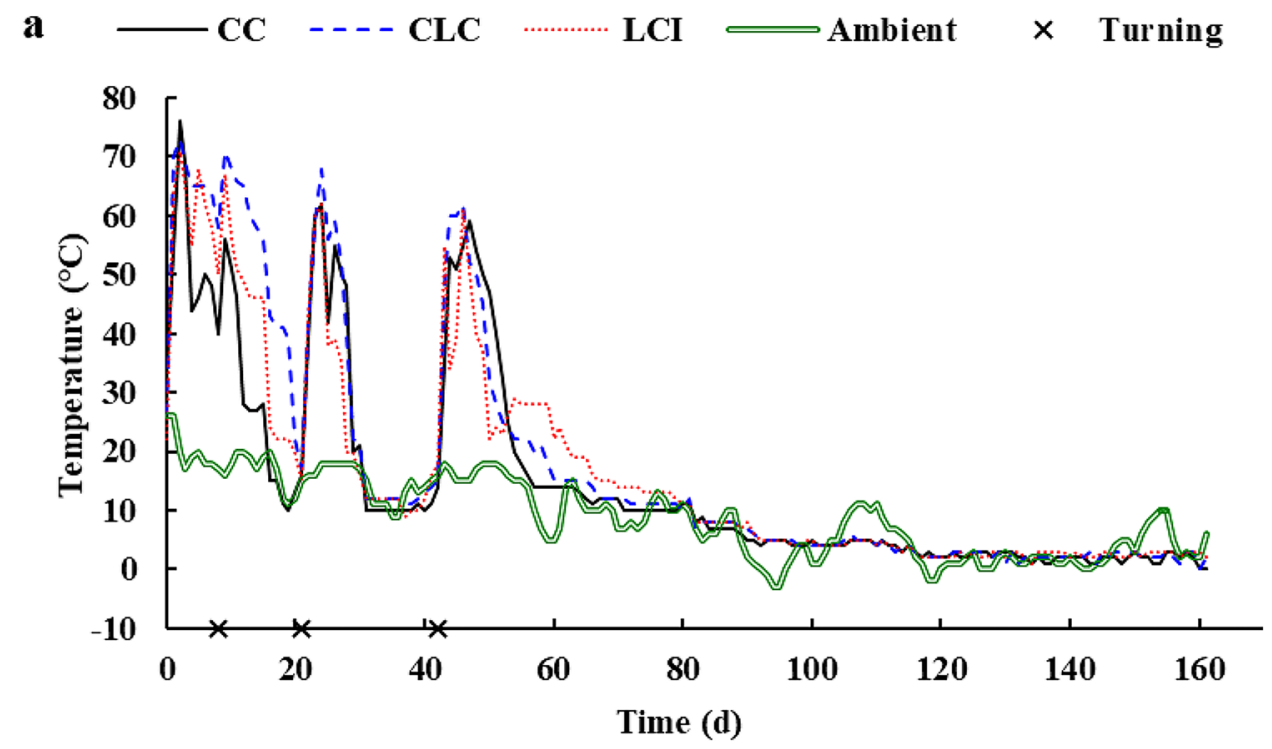

b $\rightarrow$ CC $--\star-$ CLC $\quad \cdots \cdots \cdots \cdot \cdots \cdot$ LCI

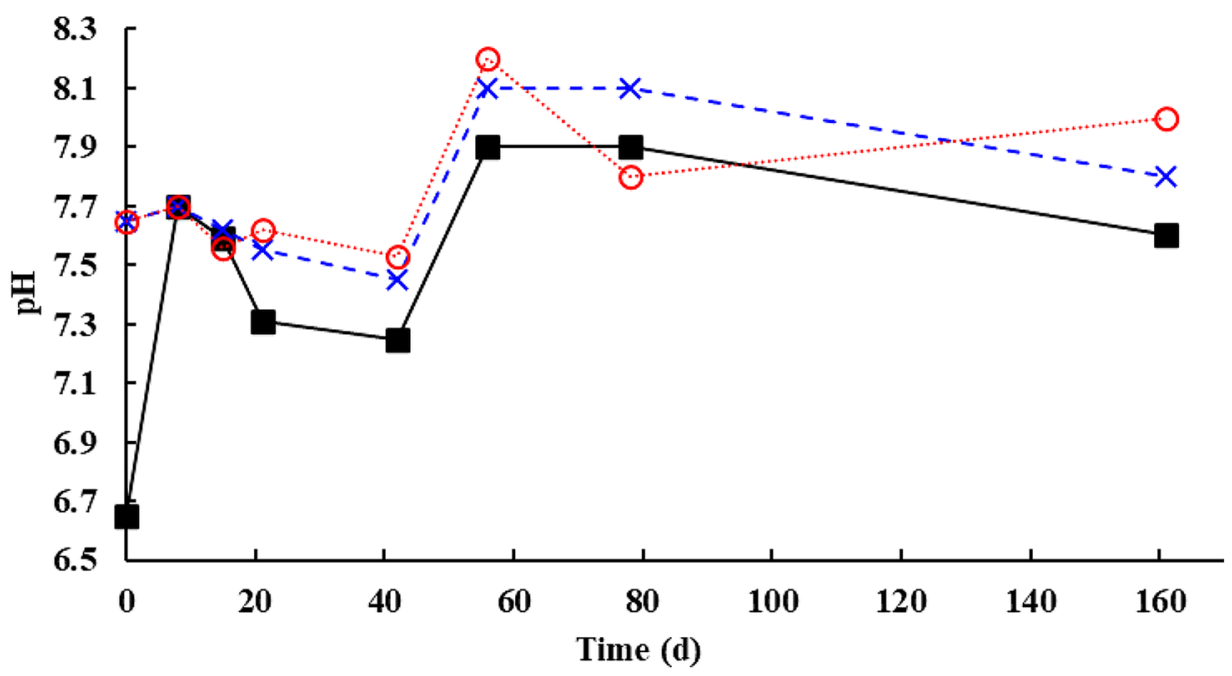

Changes in $\mathrm{OM}, \mathrm{TOC}$, and $\mathrm{TN}$ contents and $\mathrm{C} / \mathrm{N}$ ratio during the composting process were affected by the initial composition of composts (Table 2). With the progress of time, OM content declined $(p<0.05)$ in all composting bins. The initial OM percentages ranged from 86.73 to 87.27 (on dry weight basis), whereas the final values were between 76.19 and $80.90 \%$. TOC content showed a similar downward trend with advancement of composting time. Final OM and TOC percentages were significantly lower $(p<0.05)$ in LCI than in CC and CLC. As a result, LCI had the highest $K_{\mathrm{b}}$ value $(0.53)$, followed by CLC $(0.46)$ and $\mathrm{CC}(0.35)$. These results clearly indicate that the combined use of lavender waste and bacterial inoculant could enhance the depletion of OM in compost.
As far as TN content is concerned, the final percentages were higher $(p<0.05)$ than the initial ones, which must have been due the above-mentioned carbon losses (Gou et al. 2017) and the concentrating effect of weight loss associated with OM mineralization (Kausar et al. 2013). The composts were found to differ $(p<0.05)$ in final TN content because the use of lavender waste decreased the concentration of nitrogen in CLC (2.30\%) compared to CC (2.55\%). However, a higher final TN content $(p<0.05)$ was observed in LCI than in CLC due to the concentrating effect of organic matter mineralization (Sánchez-Mondero et al. 2001).

$\mathrm{C} / \mathrm{N}$ ratio is a commonly used parameter for the evaluation of compost maturity (Jusoh et al. 2013). The initial values were adjusted to between 30 and 35 (i.e., 32.43 for 
Table 2 Major chemical properties (on dry weight basis) of different types of composts at the beginning and end of the composting process

\begin{tabular}{|c|c|c|c|c|}
\hline Parameter & Day & $\mathrm{CC}$ & CLC & LCI \\
\hline \multirow[t]{2}{*}{ Organic matter $(\%)^{\mathrm{d}}$} & Initial & $86.73 \pm 0.99^{\mathrm{a}}$ & $87.27 \pm 0.14^{\mathrm{a}}$ & $87.27 \pm 0.14^{\mathrm{a}}$ \\
\hline & Final & $80.90 \pm 0.46^{\mathrm{a}}$ & $78.74 \pm 0.19^{b}$ & $76.19 \pm 0.23^{\mathrm{c}}$ \\
\hline \multirow[t]{2}{*}{ Total organic carbon $(\%)^{\mathrm{d}}$} & Initial & $48.18 \pm 0.55^{\mathrm{a}}$ & $48.48 \pm 0.08^{\mathrm{a}}$ & $48.48 \pm 0.08^{\mathrm{a}}$ \\
\hline & Final & $44.94 \pm 0.26^{\mathrm{a}}$ & $43.75 \pm 0.10^{\mathrm{b}}$ & $42.33 \pm 0.13^{\mathrm{c}}$ \\
\hline Biodegradability coefficient $\left(K_{\mathrm{b}}\right)$ & & 0.35 & 0.46 & 0.53 \\
\hline \multirow[t]{2}{*}{ Total nitrogen $(\%)^{\mathrm{d}}$} & Initial & $1.49 \pm 0.13^{\mathrm{a}}$ & $1.47 \pm 0.02^{\mathrm{a}}$ & $1.47 \pm 0.02^{\mathrm{a}}$ \\
\hline & Final & $2.55 \pm 0.02^{\mathrm{a}}$ & $2.30 \pm 0.01^{\mathrm{b}}$ & $2.50 \pm 0.03^{\mathrm{a}}$ \\
\hline \multirow[t]{2}{*}{ Carbon-to-nitrogen ratio $^{\mathrm{d}}$} & Initial & $32.43 \pm 2.45^{\mathrm{a}}$ & $32.99 \pm 0.34^{\mathrm{a}}$ & $32.99 \pm 0.34^{\mathrm{a}}$ \\
\hline & Final & $17.60 \pm 0.15^{\mathrm{b}}$ & $19.05 \pm 0.06^{\mathrm{a}}$ & $16.91 \pm 0.18^{\mathrm{c}}$ \\
\hline \multirow[t]{2}{*}{ Acid-insoluble lignin $(\%)^{\mathrm{d}}$} & Initial & $15.05 \pm 0.58^{\mathrm{a}}$ & $15.60 \pm 0.74^{\mathrm{a}}$ & $15.60 \pm 0.74^{\mathrm{a}}$ \\
\hline & Final & $14.09 \pm 0.33^{\mathrm{ab}}$ & $14.16 \pm 0.68^{\mathrm{a}}$ & $12.66 \pm 0.99^{b}$ \\
\hline
\end{tabular}

$C C$ control compost, $C L C$ control lavender waste compost, $L C I$ lavender waste compost with bacterial inoculation

${ }^{\mathrm{a}-\mathrm{c}}$ Means within a row without a common lowercase superscript differ $(p<0.05)$

${ }^{\mathrm{d}}$ Values are means \pm SD based on three observations
CC and 32.99 for CLC and LCI) with cattle manure and barley straw. After 161 days of composting, initial $\mathrm{C} / \mathrm{N}$ ratios decreased by $45.7 \%, 42.3 \%$, and $48.7 \%$ in CC, CLC, and LCI, respectively. The lowest final value of $16.91(p<0.05)$ belonged to LCI, which supports the notion that ligninolytic and cellulolytic microorganisms can accelerate the composting process. Similar results were reported by other researchers (Abdel-Rahman et al. 2016; Li et al. 2020; Liu et al. 2011; Selvamani et al. 2019; Wan et al. 2020; Zhao et al. 2017). Lignin biodegradation is also a crucial process determining the humification and stabilization of the final products and, ultimately, the length of time needed for the completion of composting (Gou et al. 2017). The initial acid-insoluble lignin content of composts was reduced by 6.4-18.8\% until the end of the composting process. The lowest final value of $12.66 \%$ was measured in LCI.

\section{Changes in microbial viability during composting}

Large and diverse communities of bacteria, actinomycetes, and fungi are actively involved in the conversion and decomposition of lignocellulosic materials (Atif et al. 2020; Varma et al. 2017). The changes in microbial viability and activity throughout the biodegradation of composting mixtures are illustrated in Fig. 2. The results show that bacteria were dominant during the whole composting process. The viable counts of mesophilic microorganisms only varied slightly despite the relatively high temperatures. The highest numbers were observed on day 21 in all three types of composts (Fig. 2a). The various treatments had different effects on the levels of thermophilic microbes (Fig. 2b). The initial viable count of thermophiles was higher in CC than in CLC or LCI. However, due to the high core temperature, their density greatly increased in CLC over the first 15 days. Thermophilic microorganisms were present at concentrations of $2.6 \times 10^{7} \mathrm{CFU} / \mathrm{g}, 7.4 \times 10^{7} \mathrm{CFU} / \mathrm{g}$, and $1.5 \times 10^{8} \mathrm{CFU} / \mathrm{g}$ in CC, CLC, and LCI, respectively, at the end of composting. The high levels of post-extraction lavender waste in CLC and LCI positively influenced the overall microbial activity.

Cellulolytic bacteria were present at high numbers (i.e., $10^{7}-10^{8} \mathrm{CFU} / \mathrm{g}$ ) in the composting materials on day 0 . The maximum viable counts of mesophilic cellulose degraders were recorded on day 8 in CC and LCI and a week later in CLC (Fig. 2c). Inoculation with the mixed culture of $C$. flavigena NCAIM B.01383 and S. viridosporus NCAIM B.02369 was shown to result in elevated mesophilic cellulolytic bacteria counts in LCI during the cooling phase (between days 56 and 161), thus providing improved conditions for compost maturation. From day 42 until the end of composting, the levels of mesophilic cellulose-degrading bacteria were lower $(p<0.05)$ in CLC than in LCI (Fig. 2c). In contrast, there were no considerable differences in the concentrations of thermophilic cellulose degraders among the three treatments throughout the entire duration of composting (Fig. 2d).

As shown in Fig. 2e, the viable counts of mesophilic streptomycetes increased relatively slowly at first, and then reached peak level on day 42 (in CLC) or day 56 (in CC and LCI). The highest value of $1.6 \times 10^{8} \mathrm{CFU} / \mathrm{g}$ was observed in LCI on day 56 . Inoculation with sporeforming and lignocellulose-degrading $S$. viridosporus NCAIM B.02369 resulted in significantly elevated levels $(p<0.05)$ of mesophilic streptomycetes in LCI, compared to the other two types of composts, during the cooling and maturation phases. As far as thermophilic streptomycetes are concerned, their lowest viable numbers were found in $\mathrm{CC}$ at almost all sampling times (Fig. 2f). Overall, the use 

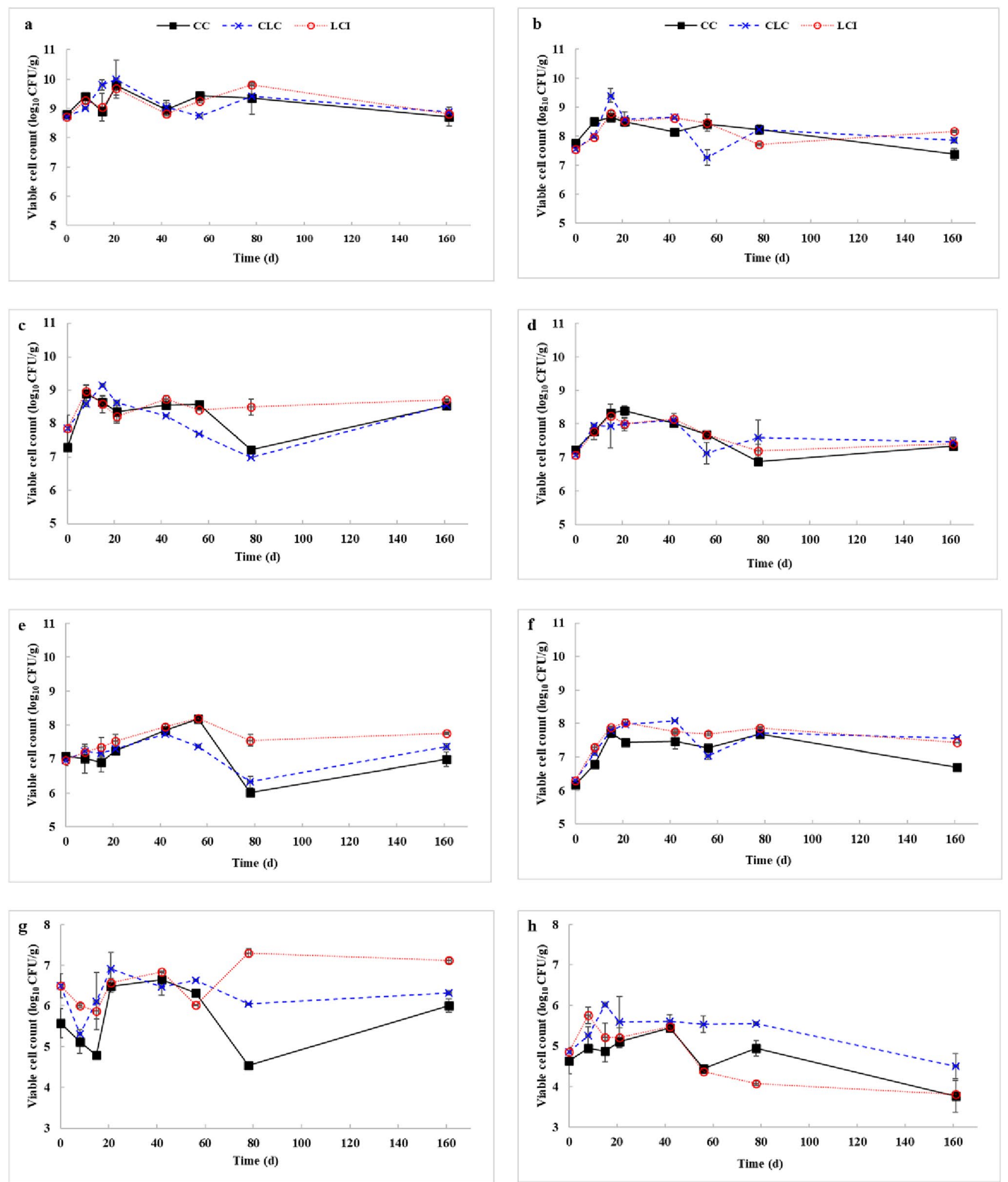

Fig. 2 Changes in viable counts of various microbial groups in different types of composts ( $C C$ control compost, $C L C$ control lavender waste compost, $L C I$ lavender waste compost with bacterial inoculation; a mesophilic microorganisms, b thermophilic microorganisms, c

mesophilic cellulolytic bacteria, $\mathbf{d}$ thermophilic cellulolytic bacteria, e mesophilic streptomycetes, $\mathbf{f}$ thermophilic streptomycetes, $\mathbf{g}$ mesophilic fungi, $\mathbf{h}$ thermophilic fungi); all data points are means \pm SD based on three observations 
of lavender waste and bacterial inoculation increased the viability and activity of streptomycetes during the composting process.

In the early thermophilic stage, fungal population sizes were basically determined by temperature. The presence of lavender waste in the composting material positively affected the initial viability of mesophilic fungi (Fig. $2 \mathrm{~g}$ ). Because of increasing compost temperatures, mesophilic fungal counts declined temporarily during the first 8 days in CLC and 15 days in CC and LCI. In contrast, the activity of thermophilic fungi was enhanced over the same period (Fig. 2h). The beneficial effects of lavender waste addition and bacterial inoculation on mesophilic fungal viability were particularly visible during the cooling phase. Thermophilic fungal counts showed a general downward trend in CLC and LCI from day 56 until the completion of composting. However, it is noteworthy that the viable numbers of thermophilic fungi were significantly higher in CLC than in LCI over the final 105 days. Core temperature declined in all three types of composts after day 78 (Fig. 1), and this resulted in decreasing the viable counts of thermophilic fungi while increasing, or at least maintaining, the viability of mesophiles. Overall, the results of microbiological analyses demonstrated that the mixed culture of C. flavigena and S. viridosporus could regulate the indigenous microbiota, thereby promoting biodegradation.

Composts were also tested for potential human pathogens, such as Salmonella spp. and E. coli (data not shown). At the start of composting, all treatments were positive for both pathogens. With the progress of time, E. coli counts declined gradually in all three types of composts. LCI was free from E. coli by day 56, whereas CC and CLC by day 78 . As from day 42, no salmonellae were detected in any compost samples. All in all, post-extraction lavender waste failed to show specific antibacterial activity against the potentially pathogenic enterobacteria tested in this study.

\section{Germination index}

GI is one of the most important parameters used to characterize and evaluate compost maturity. The initial GI values for CC, CLC, and LCI were 56.9, 21.4, and 21.4\%, respectively (Fig. 3). From day 21 to day 78, the GI values of all composts increased gradually $(67.5-73.8 \%)$, indicating that the composts had an acceptable degree of maturity $(>50 \%)$, but they still contained phytotoxic compounds influencing seed germination and root growth (Jagadabhi et al. 2019; Jiménez and Garcia 1989).

Final GI values ranged from 93.4 to $103 \%$ (Fig. 3), demonstrating that the composts were mature and free from phytotoxins. CC was especially capable of stimulating the germination of B. rapa subsp. chinensis seeds. LCI was superior to CLC in terms of GI, which must have been due to its increased TN and decreased OM contents (Table 2). Bacterial inoculation only slightly improved the maturity of the finished herbal compost.

\section{Compost maturity}

Composting is the conversion of OM to a mature and biologically stable substance (Cooperband 2000). Mature compost can be safely and easily transported, stored, and applied to the field without harming the environment (van Heerden et al. 2002). In this research, temperature, $\mathrm{C} / \mathrm{N}$ ratio, GI, and the presence or absence of potentially pathogenic enterobacteria (i.e., E. coli and Salmonella spp.) were chosen as major maturity indicators. In other studies, temperature was monitored and used to evaluate compost maturity because an
Fig. 3 Changes in germination index of Brassica rapa subsp. chinensis seeds during the composting process $(C C$ control compost, CLC control lavender waste compost, $L C I$ lavender waste compost with bacterial inoculation); values are means \pm SD based on three observations $\square C C \square C L C \square L C I$

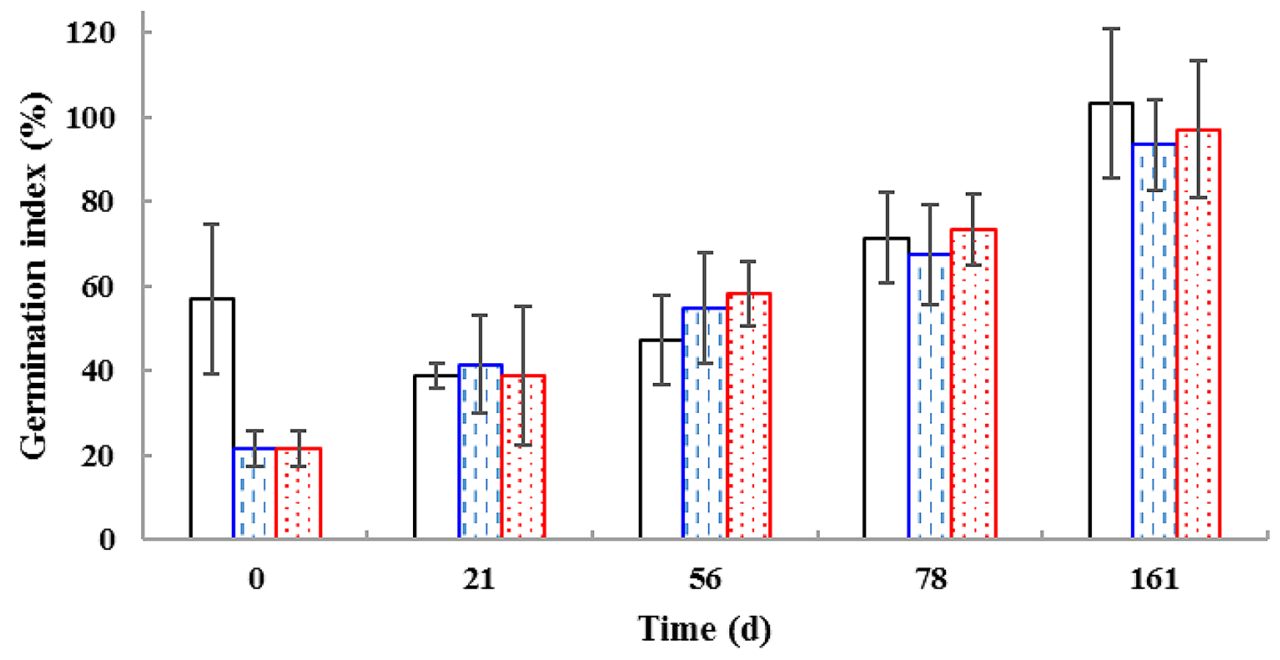


extended thermophilic stage usually results in a high-quality and safe final product (Gao et al. 2015). However, our results showed that an extension of the thermophilic phase could improve neither $\mathrm{C} / \mathrm{N}$ ratio nor GI. Only the lavender wastecontaining composts had core temperatures exceeding $55^{\circ} \mathrm{C}$ for more than three consecutive days, which is the minimum requirement for effective disinfection (Zeng et al. 2010).

$\mathrm{C} / \mathrm{N}$ ratio is widely used as an essential indicator of compost maturity (Voběrková et al. 2017). At the end of composting, LCI had a decreased value $(p<0.05)$ compared to the other two products, but the final $\mathrm{C} / \mathrm{N}$ ratio of all three treatments ranged approximately from 17 to 19 . $\mathrm{C} / \mathrm{N}$ ratios below 20 are typical of properly matured compost (Gou et al. 2017; van Heerden et al. 2002). According to Zucconi et al. (1981), GI values exceeding $80 \%$ are indicative of the disappearance of phytotoxic compounds from compost. All composts were free from phytotoxins on day 161 . CC had the highest final GI of the three types of composts. Although lavender waste addition negatively influenced this maturity indicator, bacterial inoculation was capable of mitigating the adverse effects of inhibitory residues. In addition to physical and chemical characteristics, a variety of biological properties are also considered in assessing the utility value of compost. Good biological properties include the absence of potential human pathogens in the final composting product (Bohacz 2019b). At completion of composting, all three types of product were free from salmonellae and $E$. coli even though the temperature requirements were not met in CC.

\section{Conclusions}

The use of post-extraction lavender waste positively influenced the 161-day-long composting process by extending the thermophilic stage, elevating the viable counts of beneficial bacteria and fungi, and accelerating the degradation of OM. However, negative effects were also observed, such as an increased $\mathrm{C} / \mathrm{N}$ ratio and a decreased GI. Inoculation with the mixed culture of $C$. flavigena NCAIM B.01383 and S. viridosporus NCAIM B.02369 improved the efficiency of biodegradation and preserved the nitrogen content. The bacterial inoculant reduced the $\mathrm{C} / \mathrm{N}$ ratio and enhanced the GI of the herbal compost. The Salmonella- and E. coli-free final composting products were mature and stable. These findings have demonstrated that lavender waste is a raw material suitable for composting, even though it tends to negatively influence the quality of the final product. The adverse effects of herbal residues can be reduced substantially by inoculation with specific bacteria.

Acknowledgements This research was funded by the Government of Hungary, the European Union, and the European Social Fund (grant number EFOP-3.6.3-VEKOP-16-2017-00008). This research was supported by the ÚNKP-20-3-II-SZE-16 New National Excellence Program of the Ministry for Innovation and Technology from the source of the National Research, Development and Innovation Fund.

Author contribution BG: conceptualization, methodology, investigation, formal analysis, data curation, visualization, and writingoriginal draft. JS: conceptualization, methodology, resources, funding acquisition, project administration, investigation, and validation. ÁV: conceptualization, resources, funding acquisition, and project administration. EL: resources, funding acquisition, and supervision. AS: methodology, resources, and investigation. LV: conceptualization, methodology, supervision, formal analysis, writing - review and editing. All the authors have read and agreed to the published version of the manuscript.

Funding Open access funding provided by Széchenyi István University (SZE).

\section{Declarations}

Conflict of interest Based on these results, a patent application has been submitted by Széchenyi István University and Universitas-Győr Nonprofit Ltd with J.S., B.G., E.L., A.S., and L.V. as inventors.

Open Access This article is licensed under a Creative Commons Attribution 4.0 International License, which permits use, sharing, adaptation, distribution and reproduction in any medium or format, as long as you give appropriate credit to the original author(s) and the source, provide a link to the Creative Commons licence, and indicate if changes were made. The images or other third party material in this article are included in the article's Creative Commons licence, unless indicated otherwise in a credit line to the material. If material is not included in the article's Creative Commons licence and your intended use is not permitted by statutory regulation or exceeds the permitted use, you will need to obtain permission directly from the copyright holder. To view a copy of this licence, visit http://creativecommons.org/licenses/by/4.0/.

\section{References}

Abdel-Rahman MA, El-Din MN, Refaat BM, Abdel-Shakour EH, Ewais EED, Alrefaey HMA (2016) Biotechnological application of thermotolerant cellulose-decomposing bacteria in composting of rice straw. Ann Agric Sci 61:135-143. https://doi.org/10. 1016/j.aoas.2015.11.006

Adhikari BK, Barrington S, Martinez J, King S (2009) Effectiveness of three bulking agents for food waste composting. Waste Manage 29:197-203. https://doi.org/10.1016/j.wasman.2008.04.001

Atif K, Haouas A, Aziz F, Jamali MY, Tallou A, Amir S (2020) Pathogens evolution during the composting of the household waste mixture enriched with phosphate residues and olive oil mill wastewater. Waste Biomass Valor 11:1789-1797. https://doi.org/10.1007/ s12649-018-0495-3

Bohacz J (2019a) Changes in mineral forms of nitrogen and sulfur and enzymatic activities during composting of lignocellulosic waste and chicken feathers. Environ Sci Pollut Res 26:10333-10342. https://doi.org/10.1007/s11356-019-04453-2

Bohacz J (2019b) Composts and water extracts of lignocellulosic composts in the aspect of fertilization, humus-forming, sanitary, phytosanitary and phytotoxicity value assessment. Waste Biomass Valor 10:2837-2850. https://doi.org/10.1007/s12649-018-0334-6

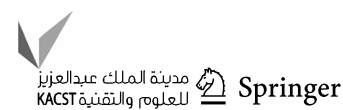


Cooperband LR (2000) Composting: art and science of organic waste conversion to a valuable soil resource. Lab Med 31:283-290. https://doi.org/10.1309/w286-lqf1-r2m2-1wnt

de Elguea-Culebras GO, Sánchez-Vioque R, Santana-Méridas O, Herraiz-Peñalver D, Carmona M, Berruga MI (2016) In vitro antifungal activity of residues from essential oil industry against Penicillium verrucosum, a common contaminant of ripening cheeses. LWT 73:226-232. https://doi.org/10.1016/j.lwt.2016.06.008

De Martino L, Mancini E, de Almeida LFR, De Feo V (2010) The antigerminative activity of twenty-seven monoterpenes. Molecules 15:6630-6637. https://doi.org/10.3390/molecules 15096630

Deka H, Deka S, Baruah CK, Das J, Hoque S, Sarma NS (2011) Vermicomposting of distillation waste of citronella plant (Cymbopogon winterianus Jowitt.) employing Eudrilus eugeniae. Bioresour Technol 102:6944-6950. https://doi.org/10.1016/j.biortech.2011. 04.027

Gao H, Zhou CB, Wang RS, Li XX (2015) Comparison and evaluation of co-composting corn stalk or rice husk with swine waste in China. Waste Biomass Valor 6:699-710. https://doi.org/10.1007/ s12649-015-9419-7

Gou CL, Wang YQ, Zhang XQ, Lou YJ, Gao YH (2017) Inoculation with a psychrotrophic-thermophilic complex microbial agent accelerates onset and promotes maturity of dairy manure-rice straw composting under cold climate conditions. Bioresour Technol 243:339-346. https://doi.org/10.1016/j.biortech.2017.06.097

Greff B, Lakatos E, Szigeti J, Varga L (2021) Co-composting with herbal wastes: potential effects of essential oil residues on microbial pathogens during composting. Crit Rev Environ Sci Technol 51:457-511. https://doi.org/10.1080/10643389.2020.1732780

Guénon R, Day TA, Velazco-Ayuso S, Gros R (2017) Mixing of Aleppo pine and Holm oak litter increases biochemical diversity and alleviates $\mathrm{N}$ limitations of microbial activity. Soil Biol Biochem 105:216-226. https://doi.org/10.1016/j.soilbio.2016.11.023

Huang HL, Zeng GM, Luo L, Zhang JC, Yu M, Qin PF (2015) Effect of inoculation during different phases of agricultural waste composting on spectroscopic characteristics of humic acid. J Cent South Univ 22:4177-4183. https://doi.org/10.1007/s11771-015-2965-0

Ibrahim MK, Mattar ZA, Abdel-Khalek HH, Azzam YM (2017) Evaluation of antibacterial efficacy of anise wastes against some multidrug resistant bacterial isolates. J Radiat Res Appl Sci 10:34-43. https://doi.org/10.1016/j.jrras.2016.11.002

ISO 657911 (2017) Microbiology of the food chain-horizontal method for the detection, enumeration and serotyping of Salmonella - part 1 detection of Salmonella spp. International Organization for Standardization (ISO), Geneva, Switzerland

Jagadabhi PS, Wani SP, Kaushal M, Patil M, Vemula AK, Rathore A (2019) Physico-chemical, microbial and phytotoxicity evaluation of composts from sorghum, finger millet and soybean straws. Int J Recycl Org Waste Agric 8:279-293. https://doi.org/10.1007/ s40093-018-0240-8

Jiang JS, Liu XL, Huang YM, Huang H (2015) Inoculation with nitrogen turnover bacterial agent appropriately increasing nitrogen and promoting maturity in pig manure composting. Waste Manage 39:78-85. https://doi.org/10.1016/j.wasman.2015.02.025

Jiménez EI, Garcia VP (1989) Evaluation of city refuse compost maturity: a review. Biol Wastes 27:115-142. https://doi.org/10.1016/ 0269-7483(89)90039-6

Jusoh MLC, Manaf LA, Latiff PA (2013) Composting of rice straw with effective microorganisms (EM) and its influence on compost quality. Iran J Environ Health Sci Eng 10:17. https://doi.org/10. 1186/1735-2746-10-17

Kausar H, Ismail MR, Saud HM, Othman R, Habib S (2013) Use of lignocellulolytic microbial consortium and $\mathrm{pH}$ amendment on composting efficacy of rice straw. Compost Sci Util 21:121-133. https://doi.org/10.1080/1065657X.2013.842131
Kebibeche H, Khelil O, Kacem M, Harche MK (2019) Addition of wood sawdust during the co-composting of sewage sludge and wheat straw influences seeds germination. Ecotoxicol Environ Saf 168:423-430. https://doi.org/10.1016/j.ecoenv.2018.10.075

Lesage-Meessen L, Bou M, Sigoillot JC, Faulds CB, Lomascolo A (2015) Essential oils and distilled straws of lavender and lavandin: a review of current use and potential application in white biotechnology. Appl Microbiol Biotechnol 99:3375-3385. https://doi.org/ 10.1007/s00253-015-6511-7

Lesage-Meessen L, Bou M, Ginies C, Chevret D, Navarro D, Drula E, Bonnin E, del Río JC, Odinot E, Bisotto A, Berrin JG, Sigoillot JC, Faulds CB, Lomascolo A (2018) Lavender- and lavandin-distilled straws: an untapped feedstock with great potential for the production of high-added value compounds and fungal enzymes. Biotechnol Biofuels 11:217. https://doi.org/10.1186/ s13068-018-1218-5

Li Y, Gu J, Zhang SQ, Shi LX, Sun W, Qian X, Dua ML, Yin YN, Wang XJ (2018) Effects of adding compound microbial inoculum on microbial community diversity and enzymatic activity during co-composting. Environ Eng Sci 35:270-278. https://doi.org/10. 1089/ees.2016.0423

Li JB, Wang XT, Cong C, Wan LB, Xu YP, Li XY, Hou FQ, Wu YY, Wang LL (2020) Inoculation of cattle manure with microbial agents increases efficiency and promotes maturity in composting. 3 Biotech 10:128. https://doi.org/10.1007/s13205-020-2127-4

Liu J, Xu XH, Li HT, Xu Y (2011) Effect of microbiological inocula on chemical and physical properties and microbial community of cow manure compost. Biomass Bioenergy 35:3433-3439. https:// doi.org/10.1016/j.biombioe.2011.03.042

López V, Nielsen B, Solas M, Ramírez MJ, Jäger AK (2017) Exploring pharmacological mechanisms of lavender (Lavandula angustifolia) essential oil on central nervous system targets. Front Pharmacol 8:280. https://doi.org/10.3389/fphar.2017.00280

Pandey AK, Gaind S, Ali A, Nain L (2009) Effect of bioaugmentation and nitrogen supplementation on composting of paddy straw. Biodegradation 20:293-306. https://doi.org/10.1007/ s10532-008-9221-3

Rajoka MI, Malik KA (1997) Cellulase production by Cellulomonas biazotea cultured in media containing different cellulosic substrates. Bioresour Technol 59:21-27. https://doi.org/10.1016/ S0960-8524(96)00136-8

Rashad FM, Saleh WD, Moselhy MA (2010) Bioconversion of rice straw and certain agro-industrial wastes to amendments for organic farming systems: 1. Composting, quality, stability and maturity indices. Bioresour Technol 101:5952-5960. https://doi. org/10.1016/j.biortech.2010.02.103

Rashed MMA, Zhang C, Ghaleb ADS, Li JP, Nagi A, Majeed H, Bakry AM, Haider J, Xu Z, Tong QN (2019) Techno-functional properties and sustainable application of nanoparticles-based Lavandula angustifolia essential oil fabricated using unsaturated lipid-carrier and biodegradable wall material. Ind Crops Prod 136:66-76. https://doi.org/10.1016/j.indcrop.2019.04.070

Ratiarisoa RV, Magniont C, Ginestet S, Oms C, Escadeillas G (2016) Assessment of distilled lavender stalks as bioaggregate for building materials: hygrothermal properties, mechanical performance and chemical interactions with mineral pozzolanic binder. Constr Build Mater 124:801-815. https://doi.org/10.1016/j.conbuildmat. 2016.08.011

Ryckeboer J, Mergaert J, Coosemans J, Deprins K, Swings J (2003) Microbiological aspects of biowaste during composting in a monitored compost bin. J Appl Microbiol 94:127-137. https://doi.org/ 10.1046/j.1365-2672.2003.01800.x

Saha A, Basak BB (2020) Scope of value addition and utilization of residual biomass from medicinal and aromatic plants. Ind Crops Prod 145:111979. https://doi.org/10.1016/j.indcrop.2019.111979 
Sánchez-Mondero MA, Roig A, Paredes C, Bernal MP (2001) Nitrogen transformation during organic waste composting by the Rutgers system and its effects on $\mathrm{pH}, \mathrm{EC}$ and maturity of the composting mixtures. Bioresour Technol 78:301-308. https://doi.org/10.1016/ S0960-8524(01)00031-1

Sánchez-Vioque R, Polissiou M, Astraka K, de los Mozos-Pascual M, Tarantilis P, Herraiz-Peñalver D, Santana-Méridas O (2013) Polyphenol composition and antioxidant and metal chelating activities of the solid residues from the essential oil industry. Ind Crops Prod 49:150-159. https://doi.org/10.1016/j.indcrop.2013.04.053

Selvamani K, Annadurai V, Soundarapandian S (2019) Improved cocomposting of poultry manure with complementary consortium of indigenous Bacillus spp. 3 Biotech 9:215. https://doi.org/10. 1007/s13205-019-1745-1

Semeniuc CA, Pop CR, Rotar AM (2017) Antibacterial activity and interactions of plant essential oil combinations against gram-positive and gram-negative bacteria. J Food Drug Anal 25:403-408. https://doi.org/10.1016/j.jfda.2016.06.002

Shaaban HAE, El-Ghorab AH, Shibamoto T (2012) Bioactivity of essential oils and their volatile aroma components: review. J Essent Oil Res 24:203-212. https://doi.org/10.1080/10412905. 2012.659528

Shang JG, Kong XR, He LL, Li WH, Liao QJH (2016) Low-cost biochar derived from herbal residue: characterization and application for ciprofloxacin adsorption. Int J Environ Sci Technol 13:2449_ 2458. https://doi.org/10.1007/s13762-016-1075-3

Singh D, Suthar S (2012) Vermicomposting of herbal pharmaceutical industry waste: earthworm growth, plant-available nutrient and microbial quality of end materials. Bioresour Technol 112:179185. https://doi.org/10.1016/j.biortech.2012.02.101

Slavov A, Ognyanov M, Vasileva I (2020) Pectic polysaccharides extracted from pot marigold (Calendula officinalis) industrial waste. Food Hydrocoll 101:105545. https://doi.org/10.1016/j. foodhyd.2019.105545

Su P, Brookes PC, He Y, Wu JJ, Xu JM (2016) An evaluation of a microbial inoculum in promoting organic $\mathrm{C}$ decomposition in a paddy soil following straw incorporation. J Soils Sediments 16:1776-1786. https://doi.org/10.1007/s11368-015-1340-y

TAPPI T 222 om-02 (2002) Acid-insoluble lignin in wood and pulp. TAPPI test methods. Technical Association of the Pulp and Paper Industry (TAPPI) Press, Atlanta, GA

Tian XP, Yang T, He JZ, Chu Q, Jia XJ, Huang J (2017) Fungal community and cellulose-degrading genes in the composting process of Chinese medicinal herbal residues. Bioresour Technol 241:374-383. https://doi.org/10.1016/j.biortech.2017.05.116

van Heerden I, Cronjé C, Swart SH, Kotzé JM (2002) Microbial, chemical and physical aspects of citrus waste composting. Bioresour Technol 81:71-76. https://doi.org/10.1016/s0960-8524(01) 00058-x

Varma VS, Das S, Sastri CV, Kalamdhad AS (2017) Microbial degradation of lignocellulosic fractions during drum composting of mixed organic waste. Sustain Environ Res 27:265-272. https:// doi.org/10.1016/j.serj.2017.05.004

Voběrková S, Vaverková MD, Burešová A, Adamcová D, Vršanská M, Kynický J, Brtnický M, Adam V (2017) Effect of inoculation with white-rot fungi and fungal consortium on the composting efficiency of municipal solid waste. Waste Manage 61:157-164. https://doi.org/10.1016/j.wasman.2016.12.039

Wan LB, Wang XT, Cong C, Li JB, Xu YP, Li XY, Hou FQ, Wu YY, Wang LL (2020) Effect of inoculating microorganisms in chicken manure composting with maize straw. Bioresour Technol 301:122730. https://doi.org/10.1016/j.biortech.2019.122730

Yazdani E, Sendi JJ, Aliakbar A, Senthil-Nathan S (2013) Effect of Lavandula angustifolia essential oil against lesser mulberry pyralid Glyphodes pyloalis Walker (Lep: Pyralidae) and identification of its major derivatives. Pestic Biochem Physiol 107:250 257. https://doi.org/10.1016/j.pestbp.2013.08.002

Yeoh CY, Chin NL, Tan CS, Ooi HS (2011) Acceleration effects of microbial inoculum on palm oil mill organic waste composting. Compost Sci Util 19:135-142. https://doi.org/10.1080/1065657X. 2011.10736989

Yohalem D, Passey T (2011) Amendment of soils with fresh and postextraction lavender (Lavandula angustifolia) and lavandin (Lavandula $\times$ intermedia) reduce inoculum of Verticillium dahliae and inhibit wilt in strawberry. Appl Soil Ecol 49:187-196. https://doi. org/10.1016/j.apsoil.2011.05.006

Zeng GM, Yu M, Chen YN, Huang DL, Zhang JC, Huang HL, Jiang RQ, Yu Z (2010) Effects of inoculation with Phanerochaete chrysosporium at various time points on enzyme activities during agricultural waste composting. Bioresour Technol 101:222-227. https://doi.org/10.1016/j.biortech.2009.08.013

Zhang JC, Zeng GM, Chen YN, Yu M, Yu Z, Li H, Yu Y, Huang H (2011) Effects of physico-chemical parameters on the bacterial and fungal communities during agricultural waste composting. Bioresour Technol 102:2950-2956. https://doi.org/10.1016/j.biort ech.2010.11.089

Zhang XX, Wang BY, Liu ZW (2019) Impacts of plant secondary metabolites from conifer litter on the decomposition of Populus purdomii litter. J For Res 30:2237-2245. https://doi.org/10.1007/ s11676-018-0766-7

Zhao Y, Zhao Y, Zhang ZC, Wei YQ, Wang HA, Lu QA, Li YJ, Wei ZM (2017) Effect of thermo-tolerant actinomycetes inoculation on cellulose degradation and the formation of humic substances during composting. Waste Manage 68:64-73. https://doi.org/10. 1016/j.wasman.2017.06.022

Zhong ZK, Bian FY, Zhang XP (2018) Testing composted bamboo residues with and without added effective microorganisms as a renewable alternative to peat in horticultural production. Ind Crops Prod 112:602-607. https://doi.org/10.1016/j.indcrop.2017. 12.043

Zhou Y, Selvam A, Wong JWC (2016) Effect of Chinese medicinal herbal residues on microbial community succession and antipathogenic properties during co-composting with food waste. Bioresour Technol 217:190-199. https://doi.org/10.1016/j.biort ech.2016.03.080

Zhou Y, Selvam A, Wong JWC (2018) Chinese medicinal herbal residues as a bulking agent for food waste composting. Bioresour Technol 249:182-188. https://doi.org/10.1016/j.biortech.2017. 09.212

Zucconi F, Pera A, Forte M, De Bertoldi M (1981) Evaluating toxicity of immature compost. Biocycle 22:54-57 